\title{
Synthesis and Antimicrobial Activity of Some Novel Heterocyclic Candidates via Michael Addition Involving 4-(4-Acetamidophenyl)-4-oxobut-2-enoic Acid
}

\author{
Maher A. EL-Hashash, ${ }^{1}$ A. Essawy, ${ }^{2}$ and Ahmed Sobhy Fawzy ${ }^{2}$ \\ ${ }^{1}$ Chemistry Department, Faculty of Science, Ain Shams University, Cairo, Egypt \\ ${ }^{2}$ Chemistry Department, Faculty of Science, Fayoum University, Fayoum, Egypt \\ Correspondence should be addressed to Ahmed Sobhy Fawzy; as1868@fayoum.edu.eg
}

Received 28 May 2014; Revised 12 August 2014; Accepted 20 August 2014; Published 10 September 2014

Academic Editor: Constantinos Pistos

Copyright (C) 2014 Maher A. EL-Hashash et al. This is an open access article distributed under the Creative Commons Attribution License, which permits unrestricted use, distribution, and reproduction in any medium, provided the original work is properly cited.

This paper discusses the utility of 4-(4-acetamidophenyl)-4-oxobut-2-enoic acid as a key starting material for the preparation of a novel series of pyridazinones, thiazoles derivatives, and other heterocycles via interaction with nitrogen, sulfur, and carbon nucleophiles under Michael addition conditions and studies the antimicrobial activities of some of these compounds.

\section{Introduction}

$\beta$-Aroylacrylic acid derivatives showed high biological activity and exhibited a broad spectrum of physiological activities [1] (fungicidal, antitumor, hypotensive, hypolipidemic, and antibacterial). Also, $\beta$-aroylacrylic acids were considered as inhibitors for phospholipase $[2,3]$ and they have antiproliferative activity against human cervix carcinoma (Hela cells) $[4,5]$. Besides that, $\beta$-aroylacrylic esters are important intermediates in field of medical science and agrochemicals [1]. Chemically, $\beta$-aroylacrylic acids are convenient polyelectrophilic reagents in the synthesis of heterocyclic compounds, for which the addition of nitrogen, sulfur, phosphorus, or carbon nucleophiles occurs exclusively at the $\alpha$-carbon of the electrophilic center of the molecule [613]. On the other hand, aryl and heteroaryl substituted (E)4-oxobut-2-enoic acids and their derivatives represent an important class of compounds with interesting pharmacological indications including antiulcer and cytoprotective properties [14] and kynurenine-3-hydroxylase [15] and human cytomegalovirus protease inhibiting activity [16]. Also several naturally occurring acylacrylic acids show notable antibiotic activity [17] and they are used as starting materials for the preparation of a novel series of pyridazinones and thiazoles, where many studies have been focused on pyridazinones which are characterized to possess good analgesic and antiinflammatory activities; besides that, these studies have indicated that the heterocyclic ring substitutions at position six and the presence of acetamide side chain that is linked to the lactam nitrogen of pyridazinone ring at position two of the pyridazinone ring improve the analgesic and antiinflammatory activities along with nil or very low ulcerogenicity [18].

The aim of this work is to study the behaviour of azaand carba-Michael addition reactions involving 4-(4-acetamidophenyl)-4-oxobut-2-enoic acid and nitrogen and/or carbon nucleophiles which is considered as a first step to prepare pyridazinones, thiazoles, and other heterocyclic compounds.

\section{Experimental}

Melting points were determined on electrothermal apparatus using open capillary method and are uncorrected. Elemental analyses were carried out by the Micro Analytical Center at Cairo University. The IR spectra were recorded on FT/IR300E Jasco spectrophotometer as potassium bromide discs. The mass spectra were run by a Shimadzu-GC-MS-QP 1000 EX apparatus at $70 \mathrm{eV} .\left({ }^{1} \mathrm{H} \&{ }^{13} \mathrm{C}\right) \mathrm{NMR}$ spectra were recorded 
on Varian Mercury $300 \mathrm{MHz}$ spectrometer using TMS as internal standard.

2.1. 4-(4-Acetamidophenyl)-4-oxobut-2-enoic Acid (1). 4(4-Acetamidophenyl)-4-oxobut-2-enoic acid was prepared according to a published procedure [19].

2.2. General Procedure for the Synthesis of Aza-Michael Adduct (2). A mixture of $\beta$-aroylacrylic acid 1 ( $4 \mathrm{mmol}$ ) and nitrogen nucleophile $(4 \mathrm{mmol})$ in dry benzene $(20 \mathrm{~mL})$ was left for 2 days. The resulting solid formed after concentration was filtered off, dried, and crystallized from ethanol and afforded the desired products.

2.2.1. 4-(4-Acetamidophenyl)-2-(benzylamino)-4-oxobutanoic Acid (2a). Yield 72\%; m.p. $236^{\circ} \mathrm{C}$; IR (KBr): 1610, 1685, 1710, 3246, 3361 and $3532 \mathrm{~cm}^{-1} ;{ }^{1} \mathrm{H}$ NMR (DMSO): $\delta$ ppm 2.08 (s, $3 \mathrm{H}, \mathrm{CH}_{3} \mathrm{CO}$ ), 3.35 (s, $2 \mathrm{H}$, methylene of benzyl moiety), 3.38 ( $\mathrm{m}, 2 \mathrm{H}$, diastereotopic methylene protons), 3.39, 3.59, 3.60, 3.95 (q, $1 \mathrm{H}$ stereogenic methine proton), 7.24, 7.26 (s, 2H, NH of amino and amide), $7.29-7.40(\mathrm{~m}, 5 \mathrm{H}$, ArH of benzyl amine moiety), 7.68, 7.72 (d, 4H, ArH), and 10.34 (s, $1 \mathrm{H}, \mathrm{COOH}) ;{ }^{13} \mathrm{C}$ NMR (DMSO): $\delta=194.11,179.7,168.3,139.95,131.97,128.91$, 127.61, 126.89, 121.21, 64.13, 51.15, 45.42 and 23.91; MS $m / z$ : $340\left[\mathrm{M}^{+}\right]$; Anal. Calcd. for $\mathrm{C}_{19} \mathrm{H}_{20} \mathrm{~N}_{2} \mathrm{O}_{4}$ : C, 67.05; H, 5.92; N, 8.23\%. Found: C, 66.92; H, 5.81; N, 8.32\%.

2.2.2. 2-[3-(Imidazole-1-yl)propylamine]-4-(4-acetamido-phenyl)-4-oxobutanoic Acid (2b). Yield 58\%; m.p. $215^{\circ} \mathrm{C}$; IR (KBr): 1604, 1680, 2600, 3409 and $3255 \mathrm{~cm}^{-1} ;{ }^{1} \mathrm{H}$ NMR (DMSO): $\delta$ ppm 2.13 (s, 3H, $\left.\mathrm{CH}_{3} \mathrm{CO}\right), 1.75,2.43,4.15(\mathrm{~m}, 6 \mathrm{H}$, $\mathrm{CH}_{2}$ of propyl group), 6.67, 7.35, $7.82(\mathrm{~m}, 3 \mathrm{H}, \mathrm{CH}$ of imidazole moiety), 7.12 (s, 1H, NH of amide), 7.97, 8.12 (m, $4 \mathrm{H}, \mathrm{ArH}) ;{ }^{13} \mathrm{C}$ NMR (DMSO): $\delta=197.5,180.9,168.8,147.8,137.7,132.4,128.9$, 128.2, 121.6, 120.5, 64.6, 47.4, 45.8, 44.2, 32.2, 23.9; MS m/z: $358\left[\mathrm{M}^{+}\right]$; Anal. Calcd. for $\mathrm{C}_{18} \mathrm{H}_{22} \mathrm{~N}_{4} \mathrm{O}_{4}: \mathrm{C}, 60.32 ; \mathrm{H}, 6.19 ; \mathrm{N}$, $15.63 \%$. Found: C, 60.15; H, 5.95; N, 15.73\%.

2.2.3. 4-(4-Acetamidophenyl)-4-oxo-2-(pyridin-2-ylmethylamino)butanoic Acid (2c). Yield 62\%; m.p. $216^{\circ} \mathrm{C}$; IR (KBr): $1615,1675,1700,3255$, and $3412 \mathrm{~cm}^{-1} ;{ }^{1} \mathrm{H}$ NMR (DMSO): $\delta$ ppm $2.10\left(\mathrm{~s}, 3 \mathrm{H}, \mathrm{CH}_{3} \mathrm{CO}\right), 3.31(\mathrm{~m}, 2 \mathrm{H}$, diastereotopic protons $\mathrm{CH}_{2}$ ), 3.82 (s, $2 \mathrm{H}, \mathrm{CH}_{2}$ of picolyl moiety), 7.15, 7.57, 8.22 (m, 4H, CH of pyridine), 7.62, $7.83(\mathrm{~m}, 4 \mathrm{H}, \mathrm{ArH}) ;{ }^{13} \mathrm{C}$ NMR (DMSO): $\delta=197.3,180.7,168.8,161.2,148.5,142.8,139.7$, 132.4, 129.1, 124.2, 121.4, 120.8, 64.2, 49.5, 45.6, 24.1; MS m/z: $341\left[\mathrm{M}^{+}\right]$; Anal. Calcd. for $\mathrm{C}_{18} \mathrm{H}_{19} \mathrm{~N}_{3} \mathrm{O}_{4}: \mathrm{C}, 63.33 ; \mathrm{H}, 5.61 ; \mathrm{N}$, $12.31 \%$. Found: C, 63.12; H, 5.49; N, 12.52\%.

2.2.4. 4-(4-Acetamidophenyl)-4-oxo-2-(3-(trimethoxysilyl)propylamino)butanoic Acid (2d). Yield 71\%; m.p. $>360^{\circ} \mathrm{C}$; IR (KBr): 1250, 1265, 1447, 1466, 1625, 1630, 1675, 1680, 3125 and $3300 \mathrm{~cm}^{-1} ;{ }^{1} \mathrm{H}$ NMR (DMSO): $\delta$ ppm 2.07 (s, 3H, $\mathrm{CH}_{3} \mathrm{CO}$ ), 3.45 (s, 9H, $\mathrm{CH}_{3}$ of methoxy), 4.12 ( $\mathrm{t}, 1 \mathrm{H}$, methine), 7.15 (s, 1H, NH of amide), 7.79, 7.85 (m, 4H, ArH); MS m/z: $312\left[\mathrm{M}^{+}\right]$; Anal. Calcd. for $\mathrm{C}_{18} \mathrm{H}_{28} \mathrm{~N}_{2} \mathrm{O}_{7} \mathrm{Si}: \mathrm{C}, 52.41 ; \mathrm{H}, 6.84$; N, 6.79\%. Found: C, 52.14; H, 6.76; N, 6.92\%.
2.2.5. 4-(4-Acetamidophenyl)-2-(4-methoxyphenylamino)-4oxobutanoic Acid (2e). Yield 79\%; m.p. 197 ${ }^{\circ}$ C; IR (KBr): 1633, 1655, 3101, $3250 \mathrm{~cm}^{-1} ;{ }^{1} \mathrm{H}$ NMR (DMSO): $\delta$ ppm 1.97 (s, 3H, $\mathrm{CH}_{3} \mathrm{CO}$ ), 2.75 (m, 2H, methylene), 3.59 (s, 3H, methoxy), 4.12 (m, 1H, methine), 6.51 (s, 4H, ArH), 7.43, 7.87 (d, 4H, $\mathrm{ArH}) ;{ }^{13} \mathrm{C}$ NMR (DMSO): $\delta=197.3,174.8,168.8,151.6,142.8$, 139.8, 132.4, 129.1, 121.4, 115.7, 115.2, 63.7, 55.9, 45.4, 24.1; MS m/z: $356\left[\mathrm{M}^{+}\right]$; Anal. Calcd. for $\mathrm{C}_{19} \mathrm{H}_{20} \mathrm{~N}_{2} \mathrm{O}_{5}$ : C, 64.04; $\mathrm{H}$, 5.66; N, 7.86\%. Found: C, 63.92; H, 5.45; N, 7.91\%.

2.2.6. 4-(4-Acetamidophenyl)-2-(3-(dimethylamino)propylamino)-4-oxobutanoic Acid (2f). Yield 75\%; m.p. $134^{\circ} \mathrm{C}$; IR (KBr): 1655, 1685, 3177, 3250, $3300 \mathrm{~cm}^{-1} ;{ }^{1} \mathrm{H}$ NMR (DMSO): $\delta$ ppm 1.35, 2.31, 2.47 (m, 6H, propyl group), $2.21(\mathrm{~s}, 3 \mathrm{H}$, $\mathrm{CH}_{3} \mathrm{CO}$ ), 2.75 (s, 6H, N-methyl groups), 2.95 (m, 2H, methylene), 4.18 ( $\mathrm{m}, 1 \mathrm{H}$, methine), 6.93 (s, 1H, NH of amide), 7.62, 7.85 (m, 4H, ArH); MS m/z: $335\left[\mathrm{M}^{+}\right]$; Anal. Calcd. for $\mathrm{C}_{17} \mathrm{H}_{25} \mathrm{~N}_{3} \mathrm{O}_{4}$ : C, 60.88; H, 7.51; N, 12.53\%. Found: C, 60.75; $\mathrm{H}, 7.33 ; \mathrm{N}, 12.64 \%$.

2.2.7. 4-(4-Acetamidophenyl)-4-oxo-2-(3-(triethoxysilyl)propylamino)butanoic Acid (2g). Yield 59\%; m.p. $>360^{\circ} \mathrm{C}$; IR (KBr): 1250, 1265, 1447, 1466, 1625, 1630, 1675, 1680, 2500, $3300 \mathrm{~cm}^{-1}$; MS m/z: $454\left[\mathrm{M}^{+}\right]$; Anal. Calcd. for $\mathrm{C}_{21} \mathrm{H}_{34} \mathrm{~N}_{2} \mathrm{O}_{7} \mathrm{Si}: \mathrm{C}, 55.48 ; \mathrm{H}, 7.54 ; \mathrm{N}, 6.16 \%$. Found: C, 55.32; $\mathrm{H}, 7.29 ; \mathrm{N}, 6.27 \%$.

2.3. 4-Benzylamino-6(4-acetamidophenyl)-2,3,4,5-tetrahydro-3(2H) Pyridazinone (3). A mixture of aza-Michael adduct $2 \mathrm{a}(1.3 \mathrm{~g}, 0.003 \mathrm{~mol})$ and hydrazine hydrate $80 \%$ $(0.5 \mathrm{~mL})$ in ethanol $(20 \mathrm{~mL})$ was refluxed for 2 hours. The reaction mixture was allowed to cool and the separated product was filtered off, dried, and crystallized from ethanol and afforded compound 3 . Yield $56 \%$ m.p. $160^{\circ} \mathrm{C}$; IR $(\mathrm{KBr})$ : 1663, 3213 and $3357 \mathrm{~cm}^{-1} ;{ }^{1} \mathrm{H}$ NMR (DMSO): $\delta$ ppm $1.75(\mathrm{~m}$, $2 \mathrm{H}$, methylene) $2.11\left(\mathrm{~s}, 3 \mathrm{H}, \mathrm{CH}_{3} \mathrm{CO}\right), 3.49\left(\mathrm{~S}, 2 \mathrm{H}, \mathrm{PhCH}_{2}\right)$, 7.35 (m, 5H, ArH of benzyl moiety), 7.85, 7.93 (m, 4H, ArH); ${ }^{13}$ C NMR (DMSO): $\delta=168.8,163,146.4,140.9,140.3,132.1$, $129.3,128.5,127.9,127.1,121.6,67.1,52.2,33.8,23.9$; MS $m / z$ : $336\left[\mathrm{M}^{+}\right]$; Anal. Calcd. for $\mathrm{C}_{19} \mathrm{H}_{20} \mathrm{~N}_{4} \mathrm{O}_{2}$ : C, 67.84; $\mathrm{H}, 5.99 ; \mathrm{N}$, $16.66 \%$. Found: C, 67.72; H, 5.86; N, 16.75\%.

2.4. (E)-3-(4-Acetamidobenzoyl)-2-(benzylamino)-4-phenylbut-3-enoic Acid (4a). A mixture of aza-Michael adduct 2a $(1.3 \mathrm{~g}, 0.003 \mathrm{~mol})$ and benzaldehyde $(0.32 \mathrm{~g}, 0.003 \mathrm{~mol})$ in ethanol $(20 \mathrm{~mL})$ was treated with few drops of triethylamine and refluxed for 2 hours. The reaction mixture was allowed to cool and the separated product was filtered off, dried, and crystallized from toluene and afforded compound $\mathbf{4 a}$. Yield 74\%; m.p. $183^{\circ} \mathrm{C}$; IR (KBr): 1604, 1651, 1686, 3176, 3252 and $3302 \mathrm{~cm}^{-1} ;{ }^{1} \mathrm{H}$ NMR (DMSO): $\delta$ ppm $2.09(\mathrm{~s}, 3 \mathrm{H}$, $\mathrm{CH}_{3} \mathrm{CO}$ ), 3.59 (s, 2H, methylene of benzyl moiety), 4.21 (s, $1 \mathrm{H}$, methine), 7.25 (s, 1H, NH of amide), 7.21, 7.45 (m, 5H, ArH of benzylamine moiety), 7.49, 7.91 ( $\mathrm{m}, 9 \mathrm{H}$, phenyl protons), 7.74 (s, $1 \mathrm{H}, \mathrm{CH}$ of methine), 10.93 (s, $1 \mathrm{H}, \mathrm{COOH}) ;{ }^{13} \mathrm{C} \mathrm{NMR}$ (DMSO): $\delta=190.32,173.91,168.73,144.12,139.92,138.19$, $134.95,134.13,131.18,128.23,126.93,121.89,60.17,51.52$ and 
24.12; MS m/z: $428\left[\mathrm{M}^{+}\right]$; Anal. Calcd. for $\mathrm{C}_{26} \mathrm{H}_{24} \mathrm{~N}_{2} \mathrm{O}_{4}$ : C, 72.88; H, 5.65; N, 6.54\%. Found: C, 72.76; H, 5.43; N, 6.62\%.

2.5. (E)-3-(4-Acetamidobenzoyl)-2-(benzylamino)-4-(pyridin2-yl)but-3-enoic Acid (4b). A mixture of aza-Michael adduct 2a $(1.3 \mathrm{~g}, 0.003 \mathrm{~mol})$ and 2-pyridinecarboxaldehyde $(0.32 \mathrm{~g}$, $0.003 \mathrm{~mol})$ in ethanol $(20 \mathrm{~mL})$ was treated with few drops of triethylamine and refluxed for 2 hours. The reaction mixture was allowed to cool and the separated product was filtered off, dried, and crystallized from toluene and afforded compound 4b. Yield 69\%; m.p. $182^{\circ} \mathrm{C}$; IR (KBr): 1608, 1655, 1685, 3175 and $3251 \mathrm{~cm}^{-1}$; ${ }^{1} \mathrm{H}$ NMR (DMSO): $\delta$ ppm 2.13 (s, 3H, $\mathrm{CH}_{3} \mathrm{CO}$ ), 3.61 (s, 2H, methylene of benzyl moiety), 7.28 (s, 1H, NH of amide), 7.22, 7.48 (m, 5H, ArH of benzylamine moiety), 7.93 ( $\mathrm{m}, 9 \mathrm{H}$, phenyl protons), 8.12 ( $\mathrm{s}, 1 \mathrm{H}$, of ethylene), $10.95(\mathrm{~s}, 1 \mathrm{H}$, $\mathrm{COOH}) ;{ }^{13} \mathrm{C}$ NMR (DMSO): $\delta=190.4,174.2,168.8,154.6$, $148.7,144.2,140.3,139.9,137.1,135.2,131.3,128.4,127.8,124.2$, 122.6, 122, 60.4 , 51.6, 24.1; MS m/z: $429\left[\mathrm{M}^{+}\right]$; Anal. Calcd. for $\mathrm{C}_{25} \mathrm{H}_{23} \mathrm{~N}_{3} \mathrm{O}_{4}$ : C, 69.92; H, 5.40; N, 9.78\%. Found: C, 69.58; H, $5.32 ; \mathrm{N}, 9.91 \%$.

2.6. General Procedure for the Synthesis of Pyridazinone Derivatives $\mathbf{5}(\boldsymbol{b}, \boldsymbol{c}, \boldsymbol{e}, \boldsymbol{f})$. A mixture of aza-Michael adducts $2(\mathbf{b}, \mathbf{c}, \mathbf{e}, \mathbf{f})(0.003 \mathrm{~mol})$ and hydrazine hydrate $80 \%(0.5 \mathrm{~mL})$ in ethanol $(20 \mathrm{~mL})$ was refluxed for 2 hours. The reaction mixture was allowed to cool and the separated product was filtered off, dried, and crystallized from ethanol and afforded compound $\mathbf{5}(\mathbf{b}, \mathbf{c}, \mathbf{e}, \mathbf{f})$.

2.6.1. N-(4-(5-(3-(1H-Imidazole-1-yl)propylamino)-6-oxo-1,4, 5,6-tetrahydropyridazin-3-yl)phenyl) Acetamide (5b). Yield 71\%; m.p. $275^{\circ} \mathrm{C}$; IR (KBr): 1621, 1650, 1666, 2962, 3286 and $3400 \mathrm{~cm}^{-1}$; ${ }^{1} \mathrm{H}$ NMR (DMSO): $\delta$ ppm 2.18 (s, 3H, $\mathrm{CH}_{3} \mathrm{CO}$ ), $3.55(\mathrm{~m}, 1 \mathrm{H}$, methine $), 1.65,2.76,4.27\left(\mathrm{~m}, 6 \mathrm{H}, \mathrm{CH}_{2}\right.$ of propyl group) $6.83,7.18,7.72(\mathrm{~m}, 3 \mathrm{H}, \mathrm{CH}$ of imidazole moiety), 7.15 (s, 1H, NH of amide), 7.51, 8.11 (m, 4H, ArH), 10.95 (s, 1H, $\mathrm{COOH}$ ); $\mathrm{MS} m / z: 354\left[\mathrm{M}^{+}\right]$; Anal. Calcd. for $\mathrm{C}_{18} \mathrm{H}_{22} \mathrm{~N}_{6} \mathrm{O}_{2}: \mathrm{C}$, $61.00 ; \mathrm{H}, 6.26 ; \mathrm{N}, 23.71 \%$. Found: C, 60.91; H, 6.15; N, 23.85\%.

2.6.2. N-(4-(6-Oxo-5-(pyridin-2-ylmethylamino)-1,4,5,6-tetrahydropyridazin-3-yl)phenyl) Acetamide (5c). Yield 73\%; m.p. over $360^{\circ} \mathrm{C}$; IR (KBr): 1616, 1670 and $3200 \mathrm{~cm}^{-1} ;{ }^{1} \mathrm{H}$ NMR (DMSO): $\delta$ ppm 2.19 (s, 3H, $\left.\mathrm{CH}_{3} \mathrm{CO}\right), 4.45$ (d, $2 \mathrm{H}$, methylene), $3.75(\mathrm{~m}, 1 \mathrm{H}$, methine), $7.34(\mathrm{~s}, 1 \mathrm{H}, \mathrm{NH}$ of acetamide), 7.52, 7.75 ( $\mathrm{m}, 4 \mathrm{H}, \mathrm{ArH}), 7.43,7.89$ and 8.57 ( $\mathrm{m}, 4 \mathrm{H}$, pyridine ring); ${ }^{13} \mathrm{C}$ NMR (DMSO): $\delta=168.8,163,161.4,148.5$, $146.4,140.9,139.7,132.1,129.5,124.2,121.8,120.8,66.9,50.3$, 33.6, 23.9; MS m/z: $337\left[\mathrm{M}^{+}\right]$; Anal. Calcd. for $\mathrm{C}_{18} \mathrm{H}_{19} \mathrm{~N}_{5} \mathrm{O}_{2}$ : C, 64.08; H, 5.68; N, 20.76\%. Found: C, 63.92; H, 5.49; N, $20.89 \%$.

2.6.3. N-(4-(5-(4-Methoxyphenylamino)-6-oxo-1,4,5,6-tetrahydropyridazin-3-yl)phenyl) Acetamide (5e). Yield 70\%; m.p. $194^{\circ} \mathrm{C}$; IR (KBr): 1600, 1668, 3189 and $3331 \mathrm{~cm}^{-1} ;{ }^{1} \mathrm{H}$ NMR (DMSO): $\delta$ ppm 1.79 ( $\mathrm{m}, 2 \mathrm{H}$, methylene of pyridazinone), 1.89 (s, 3H, $\mathrm{CH}_{3} \mathrm{CO}$ ), 3.95 (s, $3 \mathrm{H}$, of methoxy), 6.85 (m, $4 \mathrm{H}$, ArH), 7.41 (s, 1H, NH of acetamide), 7.65, 7.96 (m, 4H, ArH);
${ }^{13}$ C NMR (DMSO): $\delta=168.71,162.82,151.57,146.32,140.7$, 139.7, 132.13, 127.7, 121.54, 115.61, 115.25, 69.34, 55.69, 33.17 and 23.95; MS m/z: $352\left[\mathrm{M}^{+}\right]$; Anal. Calcd. for $\mathrm{C}_{19} \mathrm{H}_{20} \mathrm{~N}_{4} \mathrm{O}_{3}: \mathrm{C}$, 64.76; H, 5.72; N, 15.90\%. Found: C, 64.53; H, 5.58; N, 16.14\%.

2.6.4. N-(4-(5-(3-(Dimethylamino)propylamino)-6-oxo-1,4,5, 6-tetrahydropyridazin-3-yl)phenyl) Acetamide (5f). Yield 57\%; m.p. $286^{\circ} \mathrm{C}$; IR (KBr): 1600, 1649, 3108, 3187, 3262 and $3304 \mathrm{~cm}^{-1} ;{ }^{1} \mathrm{H}$ NMR (DMSO): $\delta$ ppm $1.67(\mathrm{~m}, 2 \mathrm{H}$, methylene of pyridazinone), $2.17\left(\mathrm{~s}, 3 \mathrm{H}, \mathrm{CH}_{3} \mathrm{CO}\right), 2.33$ (s, $6 \mathrm{H}, \mathrm{N}$-methyl), 1.46, 2.38, and 2.69 ( $\mathrm{m}, 6 \mathrm{H}$, propyl group), 7.39 (s, 1H, NH of acetamide), 7.52, 7.76 (m, 4H, ArH); ${ }^{13} \mathrm{C}$ NMR (DMSO): $\delta=169,146.6,140.8,132.1,129.3,121.6,67.4$, 58.9, 47.1, 45.2, 26.8, 23.9; MS m/z: $331\left[\mathrm{M}^{+}\right]$; Anal. Calcd. for $\mathrm{C}_{17} \mathrm{H}_{25} \mathrm{~N}_{5} \mathrm{O}_{2}$ : C, 61.61; H, 7.60; N, 21.13\%. Found: C, 61.43; H, 7.39; N, 21.32\%.

2.6.5. N-(4-(6-Oxo-5-(3-(trimethoxysilyl)propylamino)-1,4,5, 6-tetrahydropyridazin-3-yl)phenyl) Acetamide (5d). A mixture of keto acid $2 \mathrm{~d}(1.2 \mathrm{~g}, 0.003 \mathrm{~mol})$ and hydrazine hydrate $80 \%(0.5 \mathrm{~mL})$ in dry benzene $(20 \mathrm{~mL})$ was heated gently for 30 minutes. The reaction mixture was allowed to cool and the separated product was filtered off, dried, and crystallized from ethanol and afforded compound 5d. Yield 58\%; m.p. over $360^{\circ} \mathrm{C}$; IR (KBr): 1596, 1630, 1675, and $3180 \mathrm{~cm}^{-1} ;{ }^{1} \mathrm{H}$ NMR (DMSO): $\delta$ ppm 1.92 (m, $2 \mathrm{H}$, methylene of pyridazinone), 2.33 (s, 3H, $\mathrm{CH}_{3} \mathrm{CO}$ ), 3.68 (s, 9H, of methoxy), 7.49 (s, $1 \mathrm{H}, \mathrm{NH}$ of acetamide), 7.73, 7.91 (m, $4 \mathrm{H}, \mathrm{ArH}) ; \mathrm{MS} m / z: 408$ $\left[\mathrm{M}^{+}\right]$; Anal. Calcd. for $\mathrm{C}_{18} \mathrm{H}_{28} \mathrm{~N}_{4} \mathrm{O}_{5} \mathrm{Si}: \mathrm{C}, 52.92 ; \mathrm{H}, 6.91 ; \mathrm{N}$, $13.71 \%$. Found: C, 62.74; H, 6.82; N, 13.95\%.

2.7. $N$-(4-(2-(3-Oxo-1,2,3,4-tetrahydroquinoxalin-2-yl)acetyl) phenyl) Acetamide (6). A mixture of $\beta$-aroylacrylic acid 1 ( $1 \mathrm{~g}, 0.004 \mathrm{~mol})$ and o-phenylenediamine $(0.43 \mathrm{~g}, 0.004 \mathrm{~mol})$ in isopropyl alcohol $(20 \mathrm{~mL})$ was refluxed for 2 hours. The resulting solid formed after concentration was filtered off, dried, and crystallized from isopropyl alcohol and afforded compound 6. Yield 74\%; m.p. $220^{\circ} \mathrm{C}$; IR (KBr): 1673, 3186 and $3373 \mathrm{~cm}^{-1}$; ${ }^{1} \mathrm{H}$ NMR (DMSO): $\delta$ ppm 2.33 (s, 3H, $\mathrm{CH}_{3} \mathrm{CO}$ ), 3.45 ( $\mathrm{m}, 2 \mathrm{H}$, methylene), 4.22 ( $\mathrm{t}, 1 \mathrm{H}$ methine), 5.47, 7.95 (s, $2 \mathrm{H}$, $\mathrm{NH}$ of quinoxaline ring), 7.63, $7.84(\mathrm{~m}, 4 \mathrm{H}, \mathrm{ArH}), 6.83: 8.14$ (m, $4 \mathrm{H}$, ArH of quinoxaline); ${ }^{13} \mathrm{C}$ NMR (DMSO): $\delta=197.5$, $172.6,168.8,143,139.9,132.3,129.1,127.1,125.2,121.8,121.4$, 117.2, 114.7, 64.5, 45.8, 24.1; MS m/z: 323 [M $\left.{ }^{+}\right]$; Anal. Calcd. for $\mathrm{C}_{18} \mathrm{H}_{17} \mathrm{~N}_{3} \mathrm{O}_{3}$ : C, 66.86; H, 5.30; N, 13.00\%. Found: C, 66.73; $\mathrm{H}, 5.45 ; \mathrm{N}, 13.19 \%$.

2.8. 4-(4-Acetamidophenyl)-2-(2-hydroxyphenylamino)-4-oxobutanoic Acid (7). A mixture of $\beta$-aroylacrylic acid 1 (1 g, $0.004 \mathrm{~mol})$ and o-aminophenol $(0.44 \mathrm{~g}, 0.004 \mathrm{~mol})$ in isopropyl alcohol $(20 \mathrm{~mL})$ was refluxed for 2 hours. The resulting solid formed after concentration was filtered off, dried, and crystallized from isopropyl alcohol and afforded compound 7. Yield 62\%; m.p. $247^{\circ} \mathrm{C}$; IR (KBr): 1616, 1675, 3255 and $3394 \mathrm{~cm}^{-1}$; ${ }^{1} \mathrm{H}$ NMR (DMSO): $\delta$ ppm 2.18 (s, 3H, $\mathrm{CH}_{3} \mathrm{CO}$ ), $3.25(\mathrm{~m}, 2 \mathrm{H}$, methylene), $5.43(\mathrm{~s}, 1 \mathrm{H}, \mathrm{ArOH}), 4.15(\mathrm{~m}$, $2 \mathrm{H}$, methine), 6.82, 6.91 ( $\mathrm{m}, 4 \mathrm{H}, \mathrm{ArH}), 7.18$ (s, $1 \mathrm{H}, \mathrm{NH}$ of acetamide), 7.84, 7.89 (m, 4H, ArH); MS m/z: $342\left[\mathrm{M}^{+}\right]$; Anal. 
Calcd. for $\mathrm{C}_{18} \mathrm{H}_{18} \mathrm{~N}_{2} \mathrm{O}_{5}$ : C, 63.15; H, 5.30; N, 8.18\%. Found: C, 62.95; H, 5.19; N, 8.29\%.

2.9. $N$-(4-(2-(3-Oxopiperazin-2-yl)acetyl)phenyl) Acetamide (8). A mixture of $\beta$-aroylacrylic acid $\mathbf{1}(1 \mathrm{~g}, 0.004 \mathrm{~mol})$ and ethylenediamine $(0.26 \mathrm{~g}, 0.004 \mathrm{~mol})$ in dry benzene $(20 \mathrm{~mL})$ was refluxed for 1 hour. The resulting solid formed after concentration was filtered off, dried, and crystallized from ethanol and afforded compound 8. Yield 69\%; m.p. $204^{\circ} \mathrm{C}$; IR (KBr): 1663, 3136, 3149 and $3294 \mathrm{~cm}^{-1} ;{ }^{1} \mathrm{H}$ NMR (DMSO): $\delta$ ppm 2.37 (s, 3H, $\left.\mathrm{CH}_{3} \mathrm{CO}\right), 2.93,3.46(\mathrm{~m}, 4 \mathrm{H}$, methylene of piperazine moiety), $4.27(\mathrm{t}, 1 \mathrm{H}$, methine), $7.14(\mathrm{~s}, 1 \mathrm{H}, \mathrm{NH}$ of acetamide), 7.83, 8.11 (m, 4H, ArH); ${ }^{13} \mathrm{C} \mathrm{NMR} \mathrm{(DMSO):}$ $\delta=169.92,168.89,142.79,132.19,129.12,121.45,61.96,46.22$, 45.62, 36.43 and 24.17; MS m/z: $275\left[\mathrm{M}^{+}\right]$; Anal. Calcd. for $\mathrm{C}_{14} \mathrm{H}_{17} \mathrm{~N}_{3} \mathrm{O}_{3}$ : C, 61.08; H, 6.22; N, 15.26\%. Found: C, 61.92; $\mathrm{H}, 6.13 ; \mathrm{N}, 15.35 \%$.

2.10. N-(4-(2-(2-Amino-5-oxo-4,5-dihydrothiazol-4-yl)acetyl)phenyl) Acetamide (9). A mixture of $\beta$-aroylacrylic acid $1(1 \mathrm{~g}, 0.004 \mathrm{~mol})$ and thiourea $(0.3 \mathrm{~g}, 0.004 \mathrm{~mol})$ in ethanol $(20 \mathrm{~mL})$ and few drops of glacial acetic acid were refluxed for 2 hours. The resulting solid formed after concentration was filtered off, dried, and crystallized from ethanol and afforded compound 9. Yield 77\%; m.p. $238^{\circ} \mathrm{C}$; IR (KBr): 1602, 1650, 1681, 3300 and $3347 \mathrm{~cm}^{-1}$; ${ }^{1} \mathrm{H}$ NMR (DMSO): $\delta$ ppm 2.23 (s, 3H, $\left.\mathrm{CH}_{3} \mathrm{CO}\right), 2.91$ (m, 2H, methylene), 7.18 (s, 1H, NH of acetamide), 7.79, 7.88 (m, 4H, ArH), 8.62 (s, 2H, amino); MS m/z: $291\left[\mathrm{M}^{+}\right]$; Anal. Calcd. for $\mathrm{C}_{13} \mathrm{H}_{13} \mathrm{~N}_{3} \mathrm{O}_{3} \mathrm{~S}: \mathrm{C}, 53.60 ; \mathrm{H}$, $4.50 ; \mathrm{N}, 14.42 \%$. Found: C, 53.43; H, 4.39; N, 14.64\%.

2.11. N-(4-(6-Aminothiazolo[5,4-c]pyridazin-3-yl)phenyl) Acetamide (10). A mixture of compound $9(0.87 \mathrm{~g}, 0.003 \mathrm{~mol})$ and hydrazine hydrate $80 \%(0.5 \mathrm{~mL})$ in ethanol $(20 \mathrm{~mL})$ was refluxed for 2 hours. The reaction mixture was allowed to cool and the separated product was filtered off, dried, and crystallized from ethanol and afforded compound $\mathbf{1 0 .}$ Yield 55\%; m.p. $244^{\circ} \mathrm{C}$; IR (KBr): 1604, 1650, 3308 and 3417 $\mathrm{cm}^{-1}$; ${ }^{1} \mathrm{H}$ NMR (DMSO): $\delta$ ppm 2.13 (s, 3H, $\mathrm{CH}_{3} \mathrm{CO}$ ), 6.78 (s, 2H, amino), 7.18 (s, 1H, NH of acetamide), 7.64 (s, $1 \mathrm{H}$, of pyridazinone), 7.82, $7.93(\mathrm{~m}, 4 \mathrm{H}, \mathrm{ArH}) ;{ }^{13} \mathrm{C} \mathrm{NMR}$ (DMSO): $\delta=168.67,161.25,142.38,138.41,128.57,127.59$, 125.18, 119.59, 108.14 and 24.18; MS m/z: $285\left[\mathrm{M}^{+}\right]$; Anal. Calcd. for $\mathrm{C}_{13} \mathrm{H}_{11} \mathrm{~N}_{5} \mathrm{~S}$ : C, 54.72; H, 3.89; N, 24.55\%. Found: C, 54.63; $\mathrm{H}, 3.75$; N, 24.81\%.

2.12. N-(4-(6-Amino-4H-thiazolo[4,5-e][1,2]oxazin-3-yl)phenyl) Acetamide (11). A mixture of compound $9(0.87 \mathrm{~g}$, $0.003 \mathrm{~mol})$ and hydroxylamine hydrochloride $(0.2 \mathrm{~g}$, $0.003 \mathrm{~mol}$ ) and few drops of sodium hydroxide $30 \%$ in ethanol $(20 \mathrm{~mL})$ was refluxed for 1 hour. The reaction mixture was allowed to cool and the separated product was filtered off, dried, and crystallized from ethanol and afforded compound 11. Yield 53\%; m.p. $223^{\circ} \mathrm{C}$; IR (KBr): 1620, 1660, 3200 and $3350 \mathrm{~cm}^{-1} ;{ }^{1} \mathrm{H}$ NMR (DMSO): $\delta$ ppm 2.24 (s, 3H, $\mathrm{CH}_{3} \mathrm{CO}$ ), 4.15 (s, 2H, oxazine ring), 6.85 (s, 2H, amino), 7.21 (s, 1H, NH of acetamide), $7.55: 8.22(\mathrm{~m}, 4 \mathrm{H}, \mathrm{ArH}) ; \mathrm{MS} m / z: 288\left[\mathrm{M}^{+}\right]$;
Anal. Calcd. for $\mathrm{C}_{13} \mathrm{H}_{12} \mathrm{~N}_{4} \mathrm{O}_{2} \mathrm{~S}$ : C, 54.15; H, 4.20; N, $19.43 \%$. Found: C, 53.96; H, 4.11; N, 19.62\%.

2.13. 2-(2-(4-Acetamidophenyl)-2-oxoethyl)-3-(ethoxycarbonyl)-4-oxopentanoic Acid (12). A mixture of $\beta$-aroylacrylic acid 1 (1 g, $0.004 \mathrm{~mol})$ and ethyl acetoacetate $(0.52 \mathrm{~g}$, $0.004 \mathrm{~mol}$ ) and few drops of sodium hydroxide $30 \%$ in ethanol $(20 \mathrm{~mL})$ was left for 3 days and then acidified by $\mathrm{HCl}$ and the resulting solid formed after concentration was filtered off, dried, and crystallized from toluene and afforded compound 12. Yield 73\%; m.p. over $360^{\circ} \mathrm{C}$; IR (KBr): 1666 , 1700, 3200 and $3332 \mathrm{~cm}^{-1}$; ${ }^{1} \mathrm{H}$ NMR (DMSO): $\delta$ ppm $1.43(\mathrm{t}$, $3 \mathrm{H}, \mathrm{CH}_{3}$ of ester) 2.26 (s, 3H, $\mathrm{CH}_{3} \mathrm{CO}$ of acetamide), 2.45 (s, $3 \mathrm{H}, \mathrm{CH}_{3} \mathrm{CO}$ ), 3.11 (d, $2 \mathrm{H}$, methylene), 3.45, $3.84(\mathrm{~m}, 2 \mathrm{H}$, of 2 methine groups), 4.35 (q, $2 \mathrm{H}$, methylene of ester), 7.17 (s, $1 \mathrm{H}, \mathrm{NH}$ of acetamide), 7.63, $7.82(\mathrm{~m}, 4 \mathrm{H}, \mathrm{ArH}) ; \mathrm{MS} \mathrm{m} / z$ : $363\left[\mathrm{M}^{+}\right]$; Anal. Calcd. for $\mathrm{C}_{18} \mathrm{H}_{21} \mathrm{NO}_{7}$ : C, 59.50; H, 5.83; N, 3.85\%. Found: C, 59.34; H, 5.72; N, 3.94\%.

2.14. 2-(2-(4-Acetamidophenyl)-2-oxoethyl)-3-benzoyl-4ethoxy-4-oxobutanoic Acid (13). A mixture of $\beta$-aroylacrylic acid 1 ( $1 \mathrm{~g}, 0.004 \mathrm{~mol})$ and ethyl benzoyl acetate $(0.77 \mathrm{~g}$, $0.004 \mathrm{~mol}$ ) and few drops of sodium hydroxide $30 \%$ in ethanol $(20 \mathrm{~mL})$ was left for 2 days and then acidified by $\mathrm{HCl}$ and the resulting solid formed after concentration was filtered off, dried, and crystallized from toluene and afforded compound 13. Yield 72\%; m.p. over $360^{\circ} \mathrm{C}$; IR (KBr): 1640 , 1676, 1700, 1740, 3200 and $3415 \mathrm{~cm}^{-1} ;{ }^{1} \mathrm{H}$ NMR (DMSO): $\delta$ ppm 1.39 (t, 3H, $\mathrm{CH}_{3}$ of ester) 2.17 (s, 3H, $\left.\mathrm{CH}_{3} \mathrm{CO}\right), 3.33$ (d, $2 \mathrm{H}$, methylene), $3.95,4.23$ ( $\mathrm{m}, 2 \mathrm{H}$, of 2 methine groups), 4.42 (q, $2 \mathrm{H}$, methylene of ester), 7.19 ( $\mathrm{s}, 1 \mathrm{H}, \mathrm{NH}$ of acetamide), 7.68, 7.89 (m, 4H, ArH), 7.58, 766, 7.99 (m, 5H, ArH); ${ }^{13} \mathrm{C}$ NMR (DMSO): $\delta=197.68,195.32,178.42,169.82,168.78$, $142.71,135.35,132.87,132.11,128.46,121.29,61.16,51.58,36.13$, 30.27, 23.94 and 14.25; MS m/z: $425\left[\mathrm{M}^{+}\right]$; Anal. Calcd. for $\mathrm{C}_{23} \mathrm{H}_{23} \mathrm{NO}_{7}$ : C, 64.93; H, 5.45; N, 3.29\%. Found: C, 64.81; H, $5.39 ; \mathrm{N}, 3.34 \%$.

2.15. 2-(2-(4-Acetamidophenyl)-2-oxoethyl)-3-acetyl-4-oxopentanoic Acid (14). A mixture of $\beta$-aroylacrylic acid 1 (1 g, $0.004 \mathrm{~mol})$ and acetylacetone $(0.4 \mathrm{~g}, 0.004 \mathrm{~mol})$ and few drops of sodium hydroxide $30 \%$ in ethanol $(20 \mathrm{~mL})$ was left for 2 days and then acidified by $\mathrm{HCl}$ and the resulting solid formed after concentration was filtered off, dried, and crystallized from toluene and afforded compound $\mathbf{1 4 .}$ Yield 74\%; m.p. over $360^{\circ} \mathrm{C}$; IR (KBr): 1630, 1661, 1690, 1710, 3200 and $3428 \mathrm{~cm}^{-1} ;{ }^{1} \mathrm{H}$ NMR (DMSO): $\delta$ ppm 2.27 (s, 3H, $\mathrm{CH}_{3} \mathrm{CO}$ of acetamide), 2.45 (s, 6H, $\left.\mathrm{CH}_{3} \mathrm{CO}\right), 3.23$ (m, $2 \mathrm{H}$, methylene), $3.44,3.63$ ( $\mathrm{m}, 2 \mathrm{H}$, of 2 methine groups), 7.31 (s, $1 \mathrm{H}, \mathrm{NH}$ of acetamide), 7.59, 7.78 (m, $4 \mathrm{H}, \mathrm{ArH}) ; \mathrm{MS} \mathrm{m} / z$ : $333\left[\mathrm{M}^{+}\right]$; Anal. Calcd. for $\mathrm{C}_{17} \mathrm{H}_{19} \mathrm{NO}_{6}: \mathrm{C}, 61.25 ; \mathrm{H}, 5.75 ; \mathrm{N}$, $4.20 \%$. Found: C, 61.16; H, 5.59; N, 4.32\%.

2.16. N-(4-(1,4-Dioxo-5-phenyl-2,3,4,4a,9,9a-hexahydro-1Hpyridazino [4,5-d][1,2]diazepin-8-yl)phenyl) Acetamide (15). A mixture of compound $13(1.28 \mathrm{~g}, 0.003 \mathrm{~mol})$ and hydrazine hydrate $(80 \% 0.5 \mathrm{~mL})$ in ethanol $(20 \mathrm{~mL})$ was refluxed for 3 hours. The reaction mixture was allowed to cool and the 


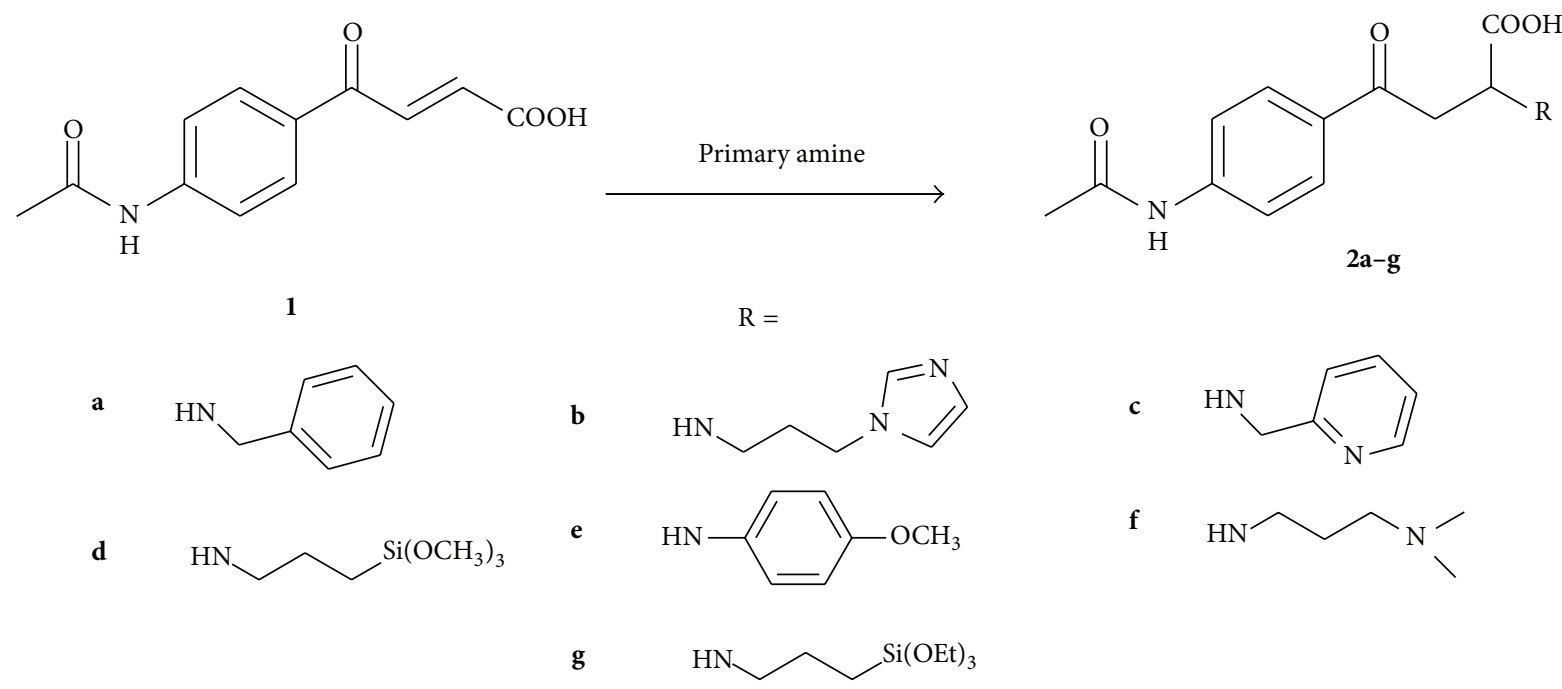

Scheme 1: Reaction of $\beta$-aroylacrylic acid $\mathbf{1}$ with primary amines.

separated product was filtered off, dried, and crystallized from ethanol and afforded compound 15 . Yield 45\%; m.p. over $360^{\circ} \mathrm{C}$; IR (KBr): $1645,1673,3241,3297$ and $3321 \mathrm{~cm}^{-1} ;{ }^{1} \mathrm{H}$ NMR (DMSO): $\delta$ ppm 1.53 (m, 2H, methylene of diazepine), $2.12\left(\mathrm{~s}, 3 \mathrm{H}, \mathrm{CH}_{3} \mathrm{CO}\right), 2.67,3.24(\mathrm{~m}, 2 \mathrm{H}$ of 2 methine of diazepine), $7.14(\mathrm{~s}, 1 \mathrm{H}, \mathrm{NH}$ of acetamide), 7.43, 7.85 (m, $5 \mathrm{H}, \operatorname{ArH}), 7.62,7.74(\mathrm{~m}, 4 \mathrm{H}, \operatorname{ArH}), 8.13$ (d, 2H, $2 \mathrm{NH}$ of pyridazinone); ${ }^{13} \mathrm{C}$ NMR (DMSO): $\delta=177.1,174.2,168.9$, 157.6, 146.5, 140.7, 134.1, 132.2, 130.9, 129.3, 128.7, 128.3, 121.6, 38.7, 26.6, 26.4, 23.9; MS m/z: $389\left[\mathrm{M}^{+}\right]$; Anal. Calcd. for $\mathrm{C}_{21} \mathrm{H}_{19} \mathrm{~N}_{5} \mathrm{O}_{3}$ : C, 64.77; H, 4.92; N, 17.98\%. Found: C, 64.61; $\mathrm{H}, 4.86 ; \mathrm{N}, 18.09 \%$.

\section{Results and Discussion}

The authors aimed through this research to study the behaviour of 4-(4-acetamidophenyl)-4-oxobut-2-enoic acid 1 towards some nitrogen nucleophiles. Thus the aza-Michael reaction of compound $\mathbf{1}$ with nitrogen nucleo-philes, namely, benzylamine, 3-(1-H-imidazole-1-yl)-propylamine, 2-picolylamine, 3-(trimethoxysilyl)propylamine, p-anisidine, 3(N,N-dimethyl)aminopropylamine, and 3-(triethoxysilyl) propylamine, in dry benzene afforded the aza-Michael adducts' compounds $(\mathbf{2 a - g})$, respectively (Scheme 1$)$. The structures of compounds (2a-g) were confirmed by elemental analysis and spectral data; EIMS of compound 2a exhibits $\mathrm{m} / \mathrm{e} 340\left(\mathrm{M}^{+}\right)$and ${ }^{1} \mathrm{H}$ NMR of compound $\mathbf{2 a}$ in DMSO shows signals at $(\delta \mathrm{ppm}) 2.08\left(\mathrm{~s}, 3 \mathrm{H}, \mathrm{CH}_{3} \mathrm{CO}\right)$, $3.35(\mathrm{~s}, 2 \mathrm{H}$, methylene of benzyl group), $3.38(\mathrm{~m}, 2 \mathrm{H}$, diastereotopic methylene protons), 3.39-3.95 (q, $1 \mathrm{H}$, stereogenic methine proton), 7.24 and 7.26 (s, $2 \mathrm{H}, \mathrm{NH}$ of amido group, exchangeable), 7.29-7.40 (m, 5H, ArH of benzylamine moiety), 7.68 and 7.72 (2d, $4 \mathrm{H}$, phenyl protons), and 10.34 (s, $1 \mathrm{H}, \mathrm{COOH}$, exchangeable).

Furthermore the structure of compound 2a was established chemically from the reaction with aromatic aldehydes (Scheme 2); when compound 2a was allowed to react with benzaldehyde and/or pyridine-2-carboxyaldehyde in boiling ethanol in the presence of triethylamine (TEA) as a base it afforded the arylidene derivatives' compounds $(\mathbf{4 a}, \mathbf{b})$. The structures of compounds $(\mathbf{4} \mathbf{a}, \mathbf{b})$ were confirmed by elemental analysis and spectral data; EIMS of compound $4 \mathbf{a}$ exhibits the molecular ion peak m/e $428\left(\mathrm{M}^{+}\right)$and ${ }^{1} \mathrm{H}$ NMR of $\mathbf{4 a}$ reveals signals at $(\delta \mathrm{ppm}) 2.09\left(\mathrm{~s}, 3 \mathrm{H}, \mathrm{CH}_{3} \mathrm{CO}\right), 3.59(\mathrm{~s}, 2 \mathrm{H}$, methylene of benzyl moiety), 7.25 (s, $1 \mathrm{H}, \mathrm{NH}$ of amide), and $10.93(\mathrm{~s}, 1 \mathrm{H}, \mathrm{COOH})$.

In the recent years a substantial number of 3- $(2 \mathrm{H})$ pyridazinones have been reported to possess antimicrobial $[20,21]$, potent analgesic [22], anti-inflammatory [22-26], antifeedant [27], herbicidal [28], antihypertensive [29-31] and antiplatelet, [32-34], anticancer [35], and other anticipated biological [9] and pharmacological properties [36, 37]. From the previous facts, authors planned to synthesize pyridazinones' derivatives through reacting acids $\mathbf{2 a}-\mathbf{f}$ with hydrazine hydrate (Schemes 2 and 3 ).

Thus when acids $\mathbf{2 a}-\mathbf{f}$ were allowed to react with hydrazine hydrate in boiling ethanol they afforded interesting pyridazinone derivatives 3 (Scheme 2 ) and (5b-f) (Scheme 3). The structures of compounds (5b-f) were ascertained by elemental analysis and spectral data; EIMS of compound 5b exhibits m/e $354\left(\mathrm{M}^{+}\right)$and ${ }^{1} \mathrm{H}$ NMR of compound $\mathbf{5 b}$ in DMSO shows signals at $(\delta \mathrm{ppm}) 2.18(\mathrm{~s}$, $\left.3 \mathrm{H}, \mathrm{CH}_{3} \mathrm{CO}\right), 3.55(\mathrm{~m}, 1 \mathrm{H}$, methine), 1.65, 2.76, and $4.27(\mathrm{~m}$, $6 \mathrm{H}, \mathrm{CH}_{2}$ of propyl group), 6.83, 7.18, and $7.72(\mathrm{~m}, 3 \mathrm{H}, \mathrm{CH}$ of imidazole moiety), 7.15 ( $\mathrm{s}, 1 \mathrm{H}, \mathrm{NH}$ of amide), 7.51 and 8.11 (m, $4 \mathrm{H}, \mathrm{ArH})$, and 10.95 (s, $1 \mathrm{H}, \mathrm{COOH})$.

However the reactions of $\alpha$ and $\beta$ unsaturated carbonyl compounds with binucleophiles provide a convenient route to interesting heterocycles (Scheme 4).

Recently [38] it was reported that $\beta$-aroylacrylic acids react with o-phenylenediamine to give quinoxalin-2-ones. Thus when compound $\mathbf{1}$ was allowed to react with ophenylenediamine in isopropyl alcohol it yielded the quinoxaline derivative compound $\mathbf{6}$; the reaction takes place via 


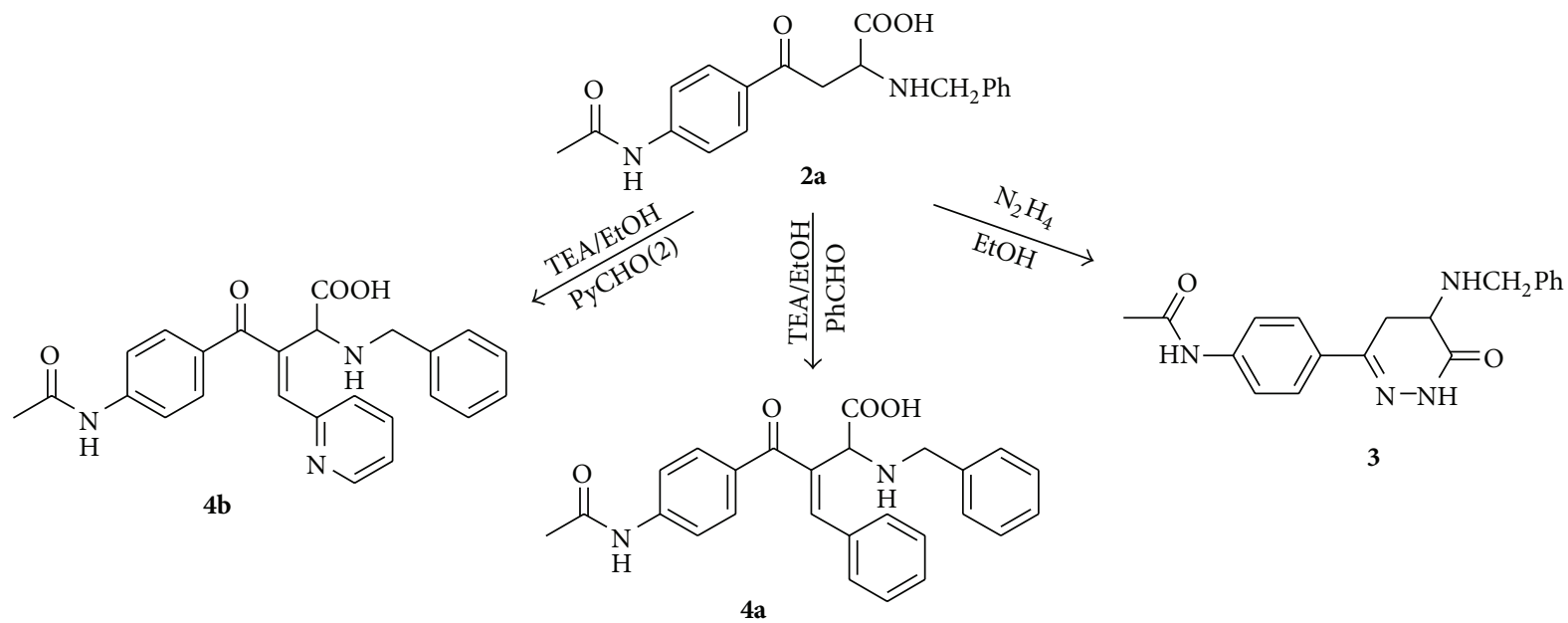

Scheme 2: Reactions of aza-Michael adduct $\mathbf{2 a}$.<smiles>CC(=O)Nc1ccc(C(=O)CC([Al])C(=O)[O-])cc1</smiles>

2b-f

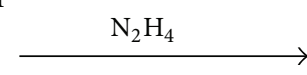

Ar<smiles>CC(=O)Nc1ccc(C2=NNC(=O)C([Al])C2)cc1</smiles>

5b-f
b $\mathrm{HN}_{\mathrm{N}}^{\rightleftharpoons}$
c $\mathrm{HN}_{\mathrm{N}}$
d $\mathrm{HN} \sim \mathrm{Si}^{2}-\mathrm{OCH}_{3}$
e<smiles>CN(C)CCCN</smiles>

SCHEme 3: Synthesis of pyridazinone derivatives.

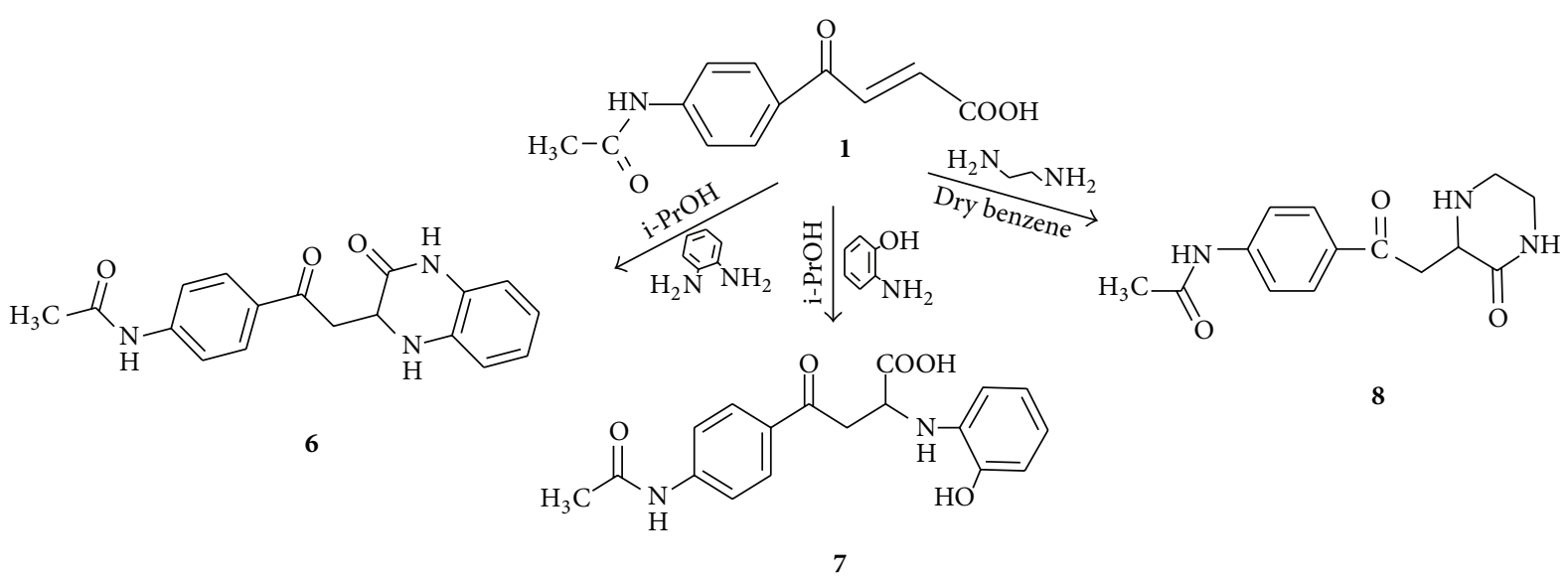

SCHEME 4: Reaction of $\beta$-aroylacrylic acid 1 with binucleophiles. 
<smiles>CC(=O)Nc1ccc(C(=O)/C=C/C(=O)O)cc1</smiles>

Scheme 5: Reaction of $\beta$-aroylacrylic acid 1 with thiourea.<smiles>CC(=O)Nc1ccc(C2=NOc3sc(N)nc3C2)cc1</smiles>

Scheme 6: Reaction of thiazole derivative 9 with hydroxyl amine and hydrazine hydrate.

aza-Michael addition followed by dehydration leading to the desired product; the structure of compound $\mathbf{6}$ was confirmed by elemental analysis and spectral data. IR spectrum of compound 6 revealed strong absorption bands at 1673, 3107, 3186,3260 , and $3373 \mathrm{~cm}^{-1}$ attributable to $v_{\mathrm{C}=\mathrm{O}}$ and $v_{\mathrm{NH}}$ bonded and nonbonded, respectively.

While the reaction of compound $\mathbf{1}$ with o-aminophenol in isopropyl alcohol afforded the aza-Michael adduct compound 7, the structure of compound 7 was confirmed by elemental analysis and spectral data. Another binucleophile, namely, ethylenediamine, was reacted with 4-(4acetamidophenyl)-4-oxobut-2-enoic acid $\mathbf{1}$ to give the piperazine derivative compound $\mathbf{8}$ via the addition of amino group to the $\alpha$ carbon of the activated double bound followed by ring closure; the structure of N-(4-(2-(3-oxopiperazin2-yl)acetyl)phenyl)acetamide 8 was confirmed by elemental analysis and spectral data; ${ }^{1} \mathrm{H}$ NMR of compound $\mathbf{8}$ in DMSO exhibits signals at $(\delta \mathrm{ppm}) 2.37\left(\mathrm{~s}, 3 \mathrm{H}, \mathrm{CH}_{3} \mathrm{CO}\right), 2.93$ and 3.46 $(\mathrm{m}, 4 \mathrm{H}$, methylene of piperazin moiety), $4.27(\mathrm{t}, 1 \mathrm{H}$, methine), $7.14(\mathrm{~s}, 1 \mathrm{H}, \mathrm{NH}$ of acetamide), and 7.83 and $8.11(\mathrm{~m}, 4 \mathrm{H}, \mathrm{ArH})$.

Previously [39], it has been reported that thiourea reacted with 4-(4-chloro-3-methyl)phenyl-4-oxobut-2-enoic acid and yielded 2-amino-4-hydroxy-5-( $4^{\prime}$-chloro- $3^{\prime}$ methyl)benzoyl methyl thiazole. This prompted us to extend the study of the behaviour of the activated olefinic double bond in 4-(4-acetamido)phenyl-4-oxobut-2-enoic acid 1 towards the same reagent. Thus when acid $\mathbf{1}$ was allowed to react with thiourea in boiling ethanol in the presence of few drops of glacial acetic acid, it afforded N-(4-(2-(2amino-5-hydroxy-thiazol-4-yl)acetyl)phenyl)acetamide $\quad 9$ (Scheme 5). The structure of compound 9 was confirmed by elemental analysis and spectral data; IR spectrum of $\mathbf{9}$ shows well-defined absorption bands attributable to $v_{\mathrm{OH}}$ and $v_{\mathrm{NH}}$ groups at 3347 and $3300 \mathrm{~cm}^{-1}$, carbonyl group bands at 1681 and $1650 \mathrm{~cm}^{-1}$, and $v_{\mathrm{C}=\mathrm{N}}$ of thiazole at $1602 \mathrm{~cm}^{-1}$.

Furthermore, the reaction of thiazole derivative 9 with hydrazine hydrate and hydroxyl amine was investigated. In this way polynuclear systems containing a thiazole ring fused with another heterocyclic ring are usually formed (Scheme 6). Condensation of 9 with hydrazine hydrate in boiling ethanol yielded $\mathrm{N}$-(4-(6-aminothiazolo[5,4c]pyridazin-3-yl)phenyl)acetamide $\mathbf{1 0}$ (Scheme 6). The reaction of the thiazole 9 with hydroxylamine hydrochloride in alcoholic sodium hydroxide affected condensation with carbonyl group and subsequent ring closure, yielding oxazine derivative compound $\mathbf{1 1}$.

The structures of compound $\mathbf{1 0}$ and compound $\mathbf{1 1}$ were confirmed by elemental analysis and spectral data; EIMS of compound 10 exhibits $\mathrm{m} / \mathrm{e} 285\left(\mathrm{M}^{+}\right)$, while $1 \mathrm{H}$ NMR of compound $\mathbf{1 1}$ in DMSO shows signals at $(\delta \mathrm{ppm}) 2.24(\mathrm{~s}$, $\left.3 \mathrm{H}, \mathrm{CH}_{3} \mathrm{CO}\right), 4.15\left(\mathrm{~s}, 2 \mathrm{H}, \mathrm{CH}_{2}\right.$ of oxazine ring), $6.85(\mathrm{~s}, 2 \mathrm{H}$, amino), 7.21 (s, $1 \mathrm{H}, \mathrm{NH}$ of acetamide), and 7.61-7.85 (m, $4 \mathrm{H}$, phenyl protons). 


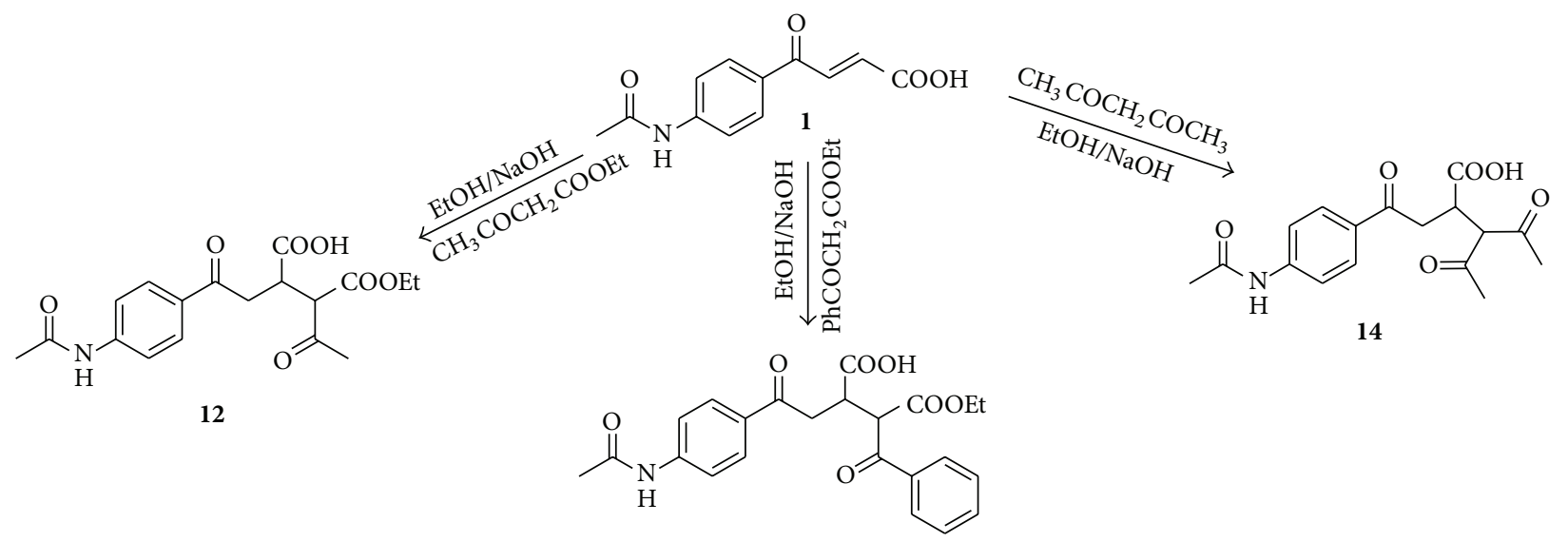

13

SCHEME 7: Reaction of $\beta$-aroylacrylic acid $\mathbf{1}$ with carbon nucleophiles.<smiles>CCOC(=O)C(C(=O)O)C(CC(=O)c1ccc(NC(C)=O)cc1)C(=O)c1ccccc1</smiles><smiles>CC(=O)Nc1ccc(C2=NN=C(c3ccccc3)C3C(=O)NNC(=O)C3CC2)cc1</smiles>

SCHEME 8: Synthesis of diazepine derivative.

On the other hand, the authors studied the behavior of 4(4-acetamidophenyl)-4-oxobut-2-enoic acid 1 towards some carbon nucleophiles under Michael reaction conditions. So when acid $\mathbf{1}$ was allowed to react with carbon nucleophiles, namely, ethyl acetoacetate, ethyl benzoylacetate, and acetylacetone, it yielded the Michael adducts 12, 13, and 14, respectively (Scheme 7).

Furthermore the interaction of Michael adduct compound 13 with hydrazine hydrate gave the diazepine derivative compound 15 (Scheme 8); the structures of compounds 12-15 were confirmed by elemental analysis and spectral data.

\section{Antimicrobial Activity}

$\beta$-Aroylacrylic acid and its derivatives represent one of the most active classes of compounds that possess a wide spectrum of biological activity. Many of these compounds have been used for the treatment of various diseases and exhibit antibacterial activity and a broad spectrum of physiological (fungicidal, antitumor, hypotensive, hypolipidemic, etc.) activities [1]. In the present work, synthesis of some $\beta$ aroylacrylic acids and their derivatives was reported. Some of the new synthesized compounds have been tested for their antimicrobial activity evaluation. Antimicrobial activity of the tested samples was determined using a modified KirbyBauer disc diffusion method [40]. Briefly, $100 \mu \mathrm{l}$ of the test bacteria was grown in $10 \mathrm{~mL}$ of fresh media (Mueller-Hinton agar) until they reached a count of approximately 108 cells $/ \mathrm{mL}$ for bacteria [41]. $100 \mu \mathrm{l}$ of microbial suspension was spread onto agar plates corresponding to the broth in which they were maintained. The tested organisms were the gram +ve bacteria (Staphylococcus aureus ATCC 25923 and Bacillus subtilis MTCC 121) and the gram -ve bacteria (Escherichia coli ATCC 25922 and Pseudomonas aeruginosa ATCC 27853), by using sterile Whatman-Nol filter paper disks $(8.0 \mathrm{~mm}$ diameter). Each compound was dissolved in DMSO. Filter paper disks were loaded with certain amount of the tested material (30 $\mu \mathrm{g} / \mathrm{disk})$ and then left with care under hot air to complete dryness. The disks were deposited on the surface of agar plates and the disks were incubated at $5^{\circ} \mathrm{C}$ for $1 \mathrm{~h}$, to permit good diffusion. All the plates were then incubated for $24 \mathrm{~h}$ at $37^{\circ} \mathrm{C}$. The diameter of inhibition zones was measured in $\mathrm{mm}$. Table 1 represents the antibacterial activity of some new synthesized compounds.

\section{Conclusions}

Novel pyridazinone, thiazole, diazepine, and other heterocyclic compounds were successfully synthesized through simple methods. The structures for the new synthesized compounds were confirmed by elemental analysis, FTIR, NMR, and mass spectra. These compounds were evaluated for in vitro antibacterial activities against some strains of bacteria. And some of them showed significant activities for both gram positive and gram negative bacteria, where it was 
TABLE 1

\begin{tabular}{|c|c|c|c|c|}
\hline \multirow[b]{2}{*}{ Sample } & \multicolumn{4}{|c|}{ Inhibition zone diameter ( $\mathrm{mm} / \mathrm{mg}$ sample) } \\
\hline & $\begin{array}{c}\text { Escherichia } \\
\text { coliATCC } 25922 \\
(\mathrm{G}-)\end{array}$ & $\begin{array}{c}\text { Pseudomonas } \\
\text { aeruginosa ATCC } \\
27853 \\
(\mathrm{G}-)\end{array}$ & $\begin{array}{c}\text { Staphylococcus } \\
\text { aureus ATCC } \\
25922 \\
(\mathrm{G}+)\end{array}$ & $\begin{array}{c}\text { Bacillus subtilis } \\
\text { MTCC } 121 \\
\text { (G+) }\end{array}$ \\
\hline $2 \mathbf{b}$ & ++ & + & + & ++ \\
\hline $2 \mathrm{e}$ & + & + & + & - \\
\hline 3 & + & - & + & + \\
\hline 6 & ++ & ++ & + & + \\
\hline 8 & + & + & + & - \\
\hline 10 & +++ & + & +++ & ++ \\
\hline 11 & ++ & ++ & ++ & - \\
\hline 15 & +++ & - & +++ & ++ \\
\hline
\end{tabular}

-: no activity, +: weak activity (diameter 5:10 mm), ++: moderate activity (diameter $10: 15 \mathrm{~mm}$ ), and +++: strong activity (diameter $>15 \mathrm{~mm}$ ).

found that compounds $\mathbf{2 b}, \mathbf{2 e}$, and $\mathbf{3}$ showed moderate to weak activity against gram +ve and gram -ve bacteria which may be due to the pyridazinone moiety, while compounds 6 and $\mathbf{8}$ showed moderate to weak activity against gram +ve and gram -ve bacteria because of quinoxaline and pyrazine moiety, and compounds $\mathbf{1 0}$ and $\mathbf{1 1}$ showed strong to moderate activity against gram +ve and gram -ve bacteria which may be due to thiazole ring; finally compound $\mathbf{1 5}$ showed strong activity against gram +ve and gram -ve bacteria because of diazepine moiety.

\section{Conflict of Interests}

The authors declare that there is no conflict of interests regarding the publication of this paper.

\section{References}

[1] K.-I. Onoue, T. Shintou, C. S. Zhang, and I. Itoh, "An efficient synthesis of $\beta$-Aroylacrylic acid ethyl ester by the Friedel-Crafts reaction in the presence of diethyl sulfate," Chemistry Letters, vol. 35, no. 1, pp. 22-23, 2006.

[2] T. Köhler, G. Friedrich, and P. Nuhn, "Phospholipase A2 inhibition by alkylbenzoylacrylic acids," Agents and Actions, vol. 32, no. 1-2, pp. 70-72, 1991.

[3] T. Köhler, M. Heinisch, M. Kirchner, G. Peinhardt, R. Hirschelmann, and P. Nuhn, "Phospholipase A2 inhibition by alkylbenzoylacrylic acids," Biochemical Pharmacology, vol. 44, no. 4, pp. 805-813, 1992.

[4] Z. Juranic, L. J. Stevovi, B. Drakuli, T. Stanojkovi, S. Radulaovi, and I. Juranic, "Substituted (E)-b-(benzoyl)acrylic acids suppressed survival of neoplastic human HeLa cells," Journal of the Serbian Chemical Society, vol. 64, pp. 505-512, 1999.

[5] B. J. Drakulic, T. P. Stanojkovic, Z. S. Zizak, and M. M. Dabovic, "Antiproliferative activity of aroylacrylic acids. Structureactivity study based on molecular interaction fields," European Journal of Medicinal Chemistry, vol. 46, no. 8, pp. 3265-3273, 2011.

[6] A. Sammour and M. Elhashash, "Alkylation of aromatic hydrocarbons with $\beta$-aroylacrylic acids," Journal für Praktische Chemie, vol. 314, no. 5-6, pp. 906-914, 1972.
[7] M. Elhashash, Y. M. Elkady, and M. M. Mohamed, "Reactions \& synthesis of 2-Aryl-3-(4-bromobenzoyl)propionic acids via Friedel Craft's alkylation of aromatic hydrocarbons with 3-(4bromobenzoyl)acrylic acid," Indian Journal of Chemistry B, vol. 18 , p. 136, 1979.

[8] S. A. Risk, M. Elhashash, and K. K. Mostafa, "Utility of $\beta$ aroyl acrylic acid in heterocyclic synthesis," Egyptian Journal of Chemistry, vol. 51, p. 611, 2008.

[9] A. S. A. Youssef, M. I. Marzouk, H. M. F. Madkour, A. M. A. El-Soll, and M. A. El-Hashash, "Synthesis of some heterocyclic systems of anticipated biological activities via 6-aryl-4-pyrazol1-yl-pyridazin-3-one," Canadian Journal of Chemistry, vol. 83, no. 3, pp. 251-259, 2005.

[10] A. S. A. Youssef, H. M. F. Madkour, M. I. Marzouk, A. M. A. ElSoll, and M. A. El-Hashash, "Utility of 3-aroylprop-2-enoic acid in heterocyclic synthesis," Afinidad, vol. 61, no. 512, pp. 304-316, 2004.

[11] M. Umpreti, S. Pant, A. Dandia, and U. C. Pant, "Synthesis of 8-substituted-2-carboxy-4-(4-fluorophenyl)-2,3-dihydro1,5-benzothiazepines," Phosphorus, Sulfur, and Silicon and the Related Elements, vol. 113, no. 1-4, pp. 165-171, 1996.

[12] A. N. Nesmeyanov, M. I. Rybinskaya, and A. I. Rybin, "Orientation of the nucleophilic attack on the activated double bond," Uspekhi Khimii, vol. 36, article 1089, 1967.

[13] R. D. Khachikyan, N. V. Karamyan, G. A. Panosyan, and M. G. Indzhikyan, "Reactions of $\beta$-aroylacrylic acids with Nnucleophiles," Akademiia nauk SSSR. Izvestiia. Seriia khimicheskaia, p. 1923, 2005.

[14] M. Bianchi, "Gastric anti-secretory, anti-ulcer and cytoprotective properties of substituted (E)-4-phenyl- and heteroaryl-4oxo-2-butenoic acids," European Journal of Medicinal Chemistry, vol. 23, no. 1, pp. 45-52, 1988.

[15] A. Giordani, "4-phenyl-4-oxo-2-butenoic acid derivatives with kynurenine-3-hydroxylase inhibiting activity," United States Patent 6048896, 2000.

[16] I. L. Pinto, R. L. Jarvest, B. Clarke et al., "Inhibition of human cytomegalovirus protease by enedione derivatives of thieno[2,3d] oxazinones through a novel dual acylation/alkylation mechanism," Bioorganic and Medicinal Chemistry Letters, vol. 9, no. 3, pp. 449-452, 1999. 
[17] C. Pfefferle, C. Kempter, J. W. Metzger, and H.-P. Fiedler, “(E)4-oxonon-2-enoic acid, an antibiotically active fatty acid produced by Streptomyces olivaceus Tü 4018," Journal of Antibiotics, vol. 49, no. 8, pp. 826-828, 1996.

[18] V. K. Chintakunta, V. Akella, M. S. Vedula et al., "3-OSubstituted benzyl pyridazinone derivatives as COX inhibitors," European Journal of Medicinal Chemistry, vol. 37, no. 4, pp. 339$347,2002$.

[19] D. Papa, E. Schwenk, F. Villani, and E. Klingsberg, “ $\beta$ Aroylacrylic acids," Journal of the American Chemical Society, vol. 70, no. 10, pp. 3356-3360, 1948.

[20] G. H. Sayed, M. A. Sayed, M. R. Mahmoud, and S. S. Shaaban, "Synthesis and reactions of new pyridazinone derivatives of expected antimicrobial activities," Egyptian Journal of Chemistry, vol. 45, pp. 767-776, 2002.

[21] A. Katrusiak, A. Katrusiak, and S. Bałoniak, "Reactivity of 6-chloro-4- and 5-hydrazino-2-phenyl-3(2H)-pyridazinones with Vilsmeier reagent," Tetrahedron, vol. 50, no. 45, pp. 1293312940, 1994.

[22] B. Okcelik, S. Unlu, E. Banoglu, E. Kupeli, E. Yesilada, and M. F. Sahin, "Investigations of new pyridazinone derivatives for the synthesis of potent analgesic and anti-inflammatory compounds with cyclooxygenase inhibitory activity," Archiv der Pharmazie, vol. 336, no. 9, pp. 406-412, 2003.

[23] D. S. Dogruer, M. F. Sahin, E. Kupeli, and E. Yesilada, "Synthesis and analgesic and anti-inflammatory activity of new pyridazinones," Turkish Journal of Chemistry, vol. 27, pp. 727-738, 2003.

[24] E. B. Frolov, F. J. Lakner, A. V. Khvat, and A. V. Ivachtchenko, "An efficient synthesis of novel 1,3-oxazolo[4,5d]pyridazinones," Tetrahedron Letters, vol. 45, no. 24, pp. 46934696, 2004.

[25] E. Banoglu, C. Akoglu, S. Unlu, E. Kupeli, E. Yesilada, and M. F. Sahin, "Amide derivatives of [6-(5-methyl-3-phenylpyrazole-1yl)-3(2H)-pyridazinone-2-yl] acetic acids as potential analgesic and anti-inflammatory compounds," Archiv der Pharmazie, vol. 337, no. 1, pp. 7-14, 2004.

[26] M. Gokçe, D. Dogruer, and M. F. Sahin, "Synthesis and antinociceptive activity of 6-substituted-3-pyridazinone derivatives," Il Farmaco, vol. 56, no. 3, pp. 233-237, 2001.

[27] S. Cao, X. Qian, G. Song, B. Chai, and Z. Jiang, "Synthesis and antifeedant activity of new oxadiazolyl $3(2 \mathrm{H})$-pyridazinones," Journal of Agricultural and Food Chemistry, vol. 51, no. 1, pp. 152-155, 2003.

[28] V. Dal Piaz, G. Ciciani, and M. P. Giovannoni, “5-Acetyl2-methyl-4-nitro-6-phenyl-3(2H)-pyridazinone: versatile precursor to hetero-condensed pyridazinones," Synthesis, no. 7, pp. 669-671, 1994.

[29] C. Öğretir, S. Yarligan, and Ş. Demirayak, "Spectroscopic determination of acid dissociation constants of some biologically active 6-phenyl-4,5-dihydro-3(2H)-pyridazinone derivatives," Journal of Chemical and Engineering Data, vol. 47, no. 6, pp. 1396-1400, 2002.

[30] R. Barbaro, L. Betti, M. Botta et al., "Synthesis, biological evaluation, and pharmacophore generation of new pyridazinone derivatives with affinity toward $\alpha 1$ - and $\alpha 2$-adrenoceptors," Journal of Medicinal Chemistry, vol. 44, no. 13, pp. 2118-2132, 2001.

[31] I. Sircar, "Synthesis of new 1,2,4-triazolo[4,3-b]pyridazines and related compounds," Journal of Heterocyclic Chemistry, vol. 22, no. 4, pp. 1045-1048, 1985.
[32] A. Coelho, E. Sotelo, N. Fraiz et al., "Pyridazines. Part 36: Synthesis and antiplatelet activity of 5-substituted-6-phenyl-3 $(2 \mathrm{H})$ -pyridazinones," Bioorganic \& Medicinal Chemistry Letters, vol. 14, pp. 321-324, 2004.

[33] E. Sotelo, N. B. Centeno, J. Rodrigo, and E. Ravina, "Pyridazine derivatives. Part 27: A joint theoretical and experimental approach to the synthesis of 6-phenyl-4,5-disubstituted-3(2H)pyridazinones," Tetrahedron Letters, vol. 58, pp. 2389-2395, 2002.

[34] E. Sotelo, N. Fraiz, M. Yáez et al., "Pyridazines. Part XXIX: synthesis and platelet aggregation inhibition activity of 5substituted-6-phenyl-3(2H)-pyridazinones. Novel aspects of their biological actions," Bioorganic and Medicinal Chemistry, vol. 10, no. 9, pp. 2873-2882, 2002.

[35] W. Malinka, A. Redzicka, and O. Lozach, "New derivatives of pyrrolo[3,4-d]pyridazinone and their anticancer effects," Il Farmaco, vol. 59, pp. 457-462, 2004.

[36] E. Sotelo, B. Pita, and E. Raviña, "Pyridazines. Part 22: highly efficient synthesis of pharmacologically useful 4-cyano6-phenyl-5-substituted-3(2H)-pyridazinones," Tetrahedron Letters, vol. 41, no. 16, pp. 2863-2866, 2000.

[37] E. Sotelo, A. Coelho, and E. Ravina, "Pyridazine derivatives 32: stille-based approaches in the synthesis of 5-substituted6-phenyl-3(2H)-pyridazinones," Chemical and Pharmaceutical Bulletin, vol. 51, no. 4, pp. 427-430, 2003.

[38] N. N. Kolos, L. Y. Kovalenko, S. V. Shishkina, O. V. Shishkin, and I. S. Konovalova, "Interaction of esters of $\beta$-aroylacrylic acids with $o$-phenylenediamines and 1,2-diamino-4-phenylimidazole," Chemistry of Heterocyclic Compounds, vol. 43, no. 11, pp. 1397-1405, 2007.

[39] M. El-Kady, M. A. El-Hashash, and M. A. Sayed, "Action of Hydrazine,Amine and Thiourea upon 3-(4-chloro-3methyl)benzoyl acrylic acid," Revue Roumaine de Chimie, vol. 26, no. 8, pp. 1161-1167, 1981.

[40] A. W. Bauer, W. M. Kirby, J. C. Sherris, and M. Turck, "Antibiotic susceptibility testing by a standardized single disk method," The American Journal of Clinical Pathology, vol. 45, no. 4, pp. 493496, 1966.

[41] M. A. Pfaller, L. Burmeister, M. S. Bartlett, and M. G. Rinaldi, "Multicenter evaluation of four methods of yeast inoculum preparation," Journal of Clinical Microbiology, vol. 26, no. 8, pp. 1437-1441, 1988. 

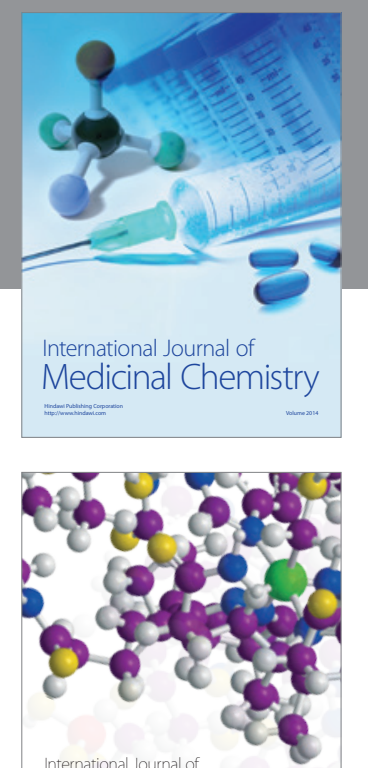

\section{Carbohydrate} Chemistry

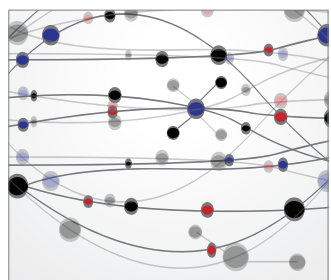

The Scientific World Journal
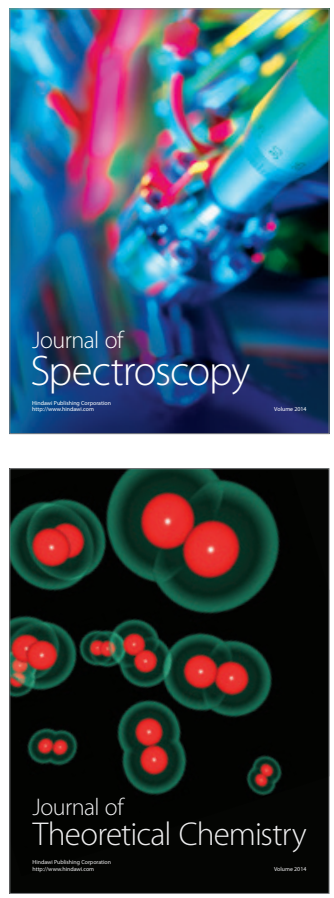
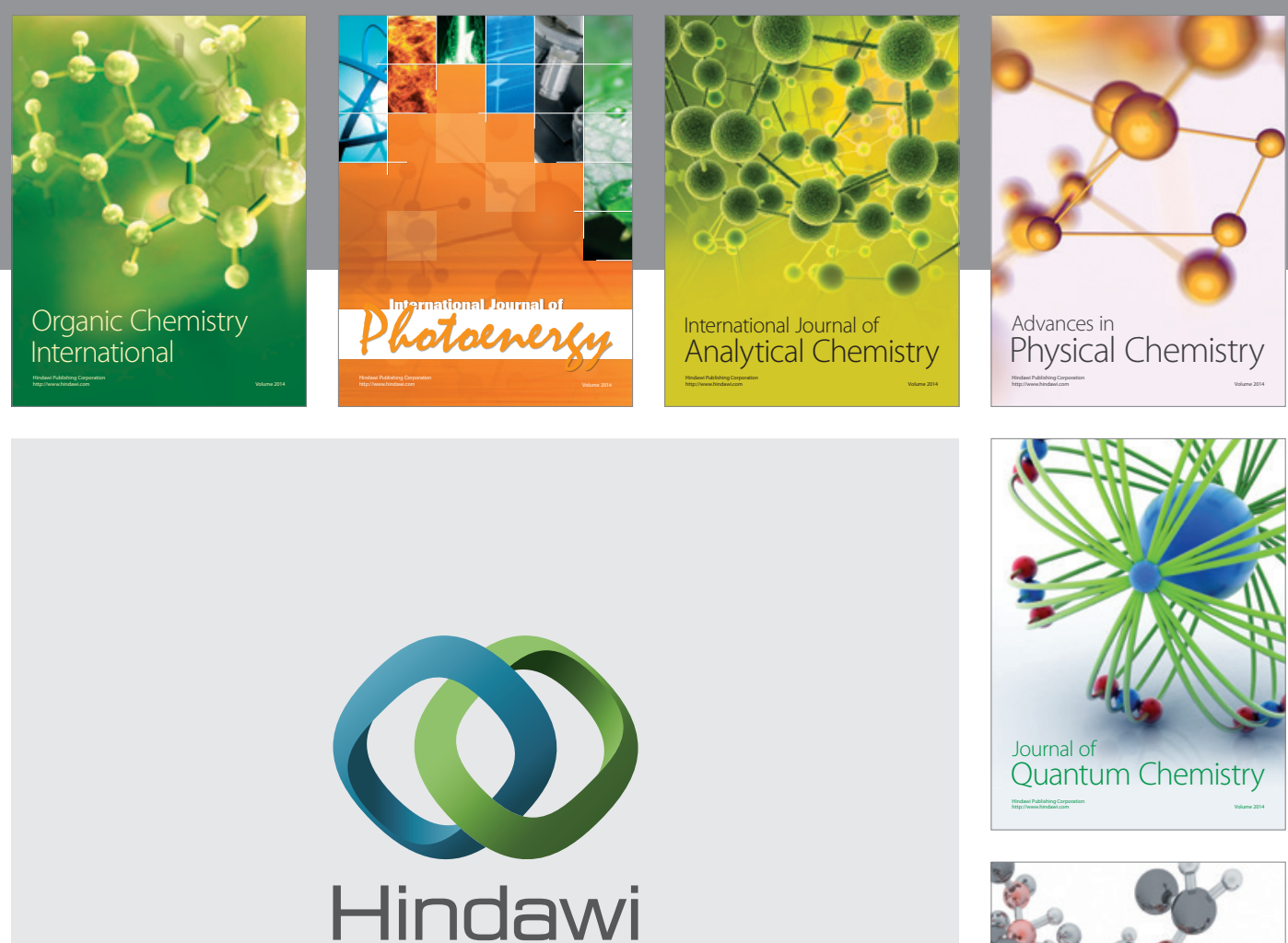

Submit your manuscripts at

http://www.hindawi.com

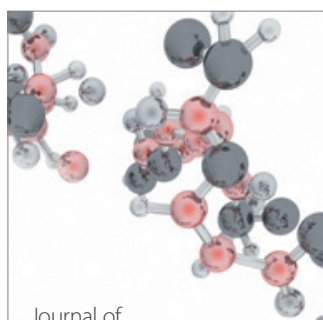

Analytical Methods

in Chemistry

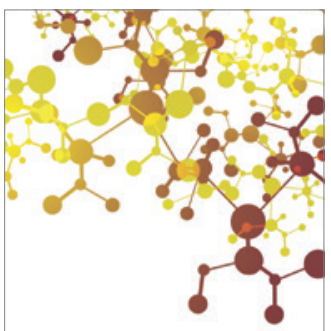

Journal of

Applied Chemistry

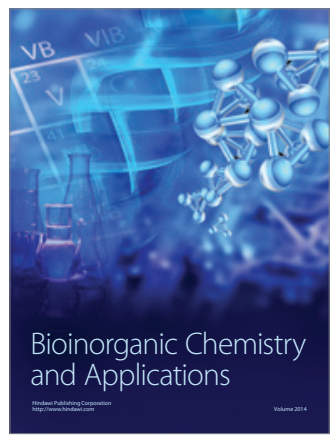

Inorganic Chemistry
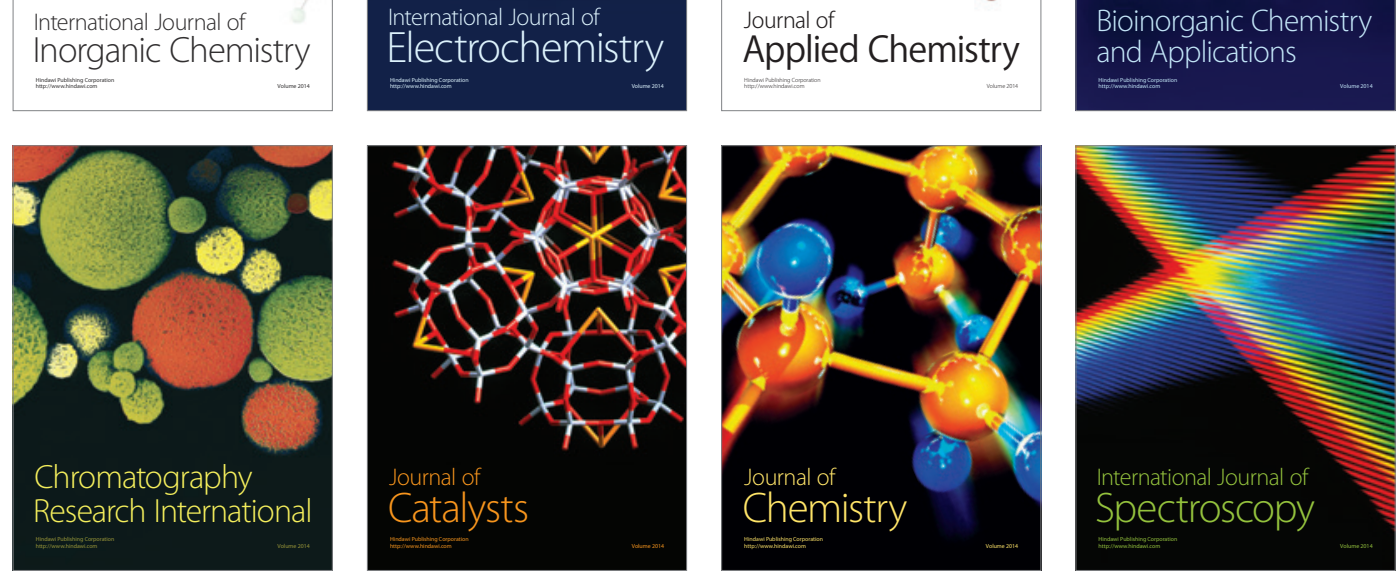